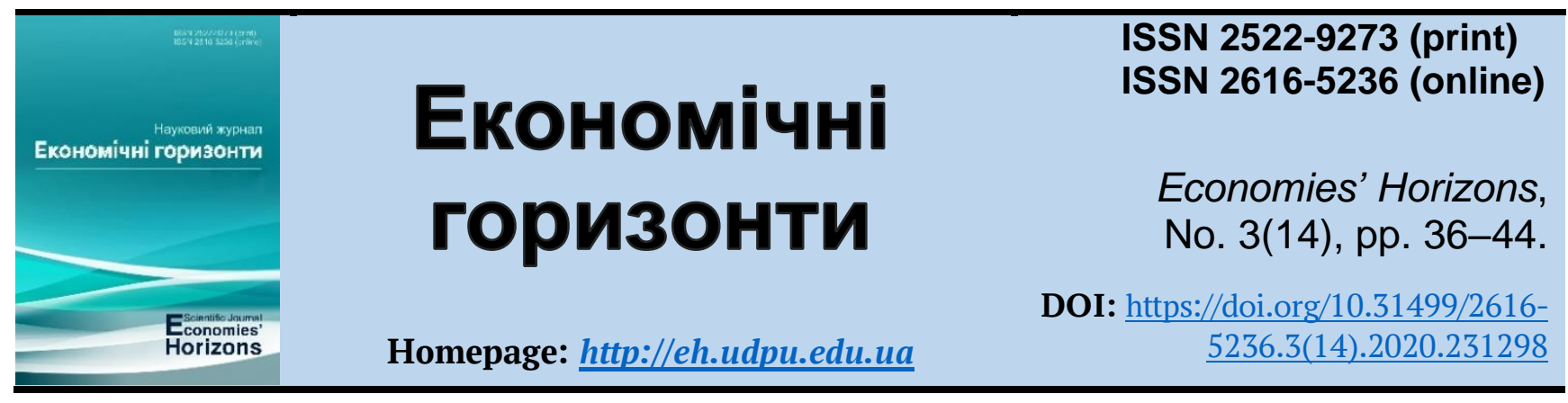

UDC 351.863

\title{
Research methodology in the system of financial and economic security
}

\author{
Lida P. Rogatina ${ }^{1}$, Doct. Ec. Sc., Associate Professor
}

Received: 2 August 2020

Accepted: 13 September 2020 Rogatina, L. P. (2020), "Research methodology in the system of financial and economic
security", $\quad$ Economies' Horizons, no. 3(14), pp. 36-44,
https://doi.org/10.31499/2616-5236.3(14).2020.231298

\begin{abstract}
The purpose of the article is to form a methodology of scientific research in the system of financial and economic security. Methodology. The scientific works of scientists in the study of financial and economic security are the theoretical and methodological basis of the study. To achieve the study's purpose, the following research methods were used: theoretical generalization - the essence and main components of the system of financial and economic security; methods of positive and normative analysis - to make recommendations on the methodology of scientific research in the system of financial and economic security. Results. Research in the financial and economic security system has been proven to be carried out in five areas. Among the areas of research of the system of financial and economic security are dangerous processes and phenomena occurring in the world economy that can negatively affect the economic security of Ukraine; the level of stability, protection of interests, and opportunities of the national economy to counteract the negative impact of the crisis of the world economy; the state of economic security of Ukraine and trends in the development of adverse factors in the national economy and the formation of mechanisms to counter them; the state of economic security of economic entities, external and internal factors of dangers and threats to economic security; features of the organization of the system of economic security of enterprises, the activities of the subjects of its provision and their use of techniques and technologies that make it possible to ensure economic security. The basic principles of research methodology in the system of financial and economic security have been provided. The principles of research methodology in the system of financial and economic security include the principle of conformity (responsible for building a system of definitions of basic concepts, axioms based on these definitions, theorems of the theory of economic security); the principle of additionality (allows the establishment of the place of the theory of economic security in the structure of economic science); the principle of hierarchical goals (ensuring the security of the upper level of the economic system is a condition for ensuring the economic security of the lower level of the economic system); the principle of relative independence of horizontal goals, methodological consistency, spatial consistency. Indicative, resource-functional, and program-target have been proven to be among the methodological approaches to the study of the system of financial and economic security. Practical significance. The methodology of scientific research in the system of financial and economic security, which can be used by applicants and scientific and pedagogical workers of higher edu-
\end{abstract}

\footnotetext{
${ }^{1}$ Odessa National Academy of Food Technologies; Head of the Department of Economic Theory and Financial and Economic Security; ORCID ID: https://orcid.org/0000-0002-1055-810X; e-mail: rogatina.lida@gmail.com.
} 
cation, is provided. Prospects for further research. Selection of the optimal methodology of scientific research in the formation of the system of financial and economic security.

Keywords: methodology, methodological approaches, methods, financial and economic security.

JEL Classification: B00, B41, B49, E00, J18

Number of references: 12; number of tables: 1; number of figures: $\mathbf{1}$; number of formulas: $\mathbf{0}$.

\title{
Методологія наукових досліджень у системі фінансово-економічної безпеки
}

\author{
Ліда Петрівна Рогатіна ${ }^{1}$, д. е. н., доцент
}

Стаття надійшла: 02.08.2020 Стаття прийнята: 13.09.2020
Rogatina L. P. Research methodology in the system of financial and economic security. Економічні горизонти. 2020. № 3(14). C. 36-44. DOI: 10.31499/2616$\underline{5236.3(14) .2020 .231298}$

Анотація. Метою статті є дослідження сутності, завдань та методичних підходів організація наукових досліджень в системі фінансово-економічної безпеки. Методологія. Теоретичною і методологічною основою дослідження $\epsilon$ наукові праці вчених в організації наукових досліджень системи фінансово-економічної безпеки. Для досягнення поставленої в роботі мети були використані такі методи дослідження: теоретичне узагальнення - сутності, системи показників оцінювання фінансово-економічної безпеки; методи позитивного і нормативного аналізу - для вироблення рекомендацій щодо удосконалення організації наукових досліджень в системі фінансово-економічної безпеки. Результати. Досліджено сутність визначення поняття «система фінансово-економічна безпека». Визначено, що єдиного підходу до визначення сутності поняття «фінансово-економічна безпека» серед вітчизняних науковців відсутнє. Доведено, що вітчизняні науковці фінансово-економічну безпеку розрізняють 3 різних підходів. Виділяють наступні підходи до розуміння сутності поняття економічної безпеки підприємства як захист від: несанкціонованого доступу до інформації; методів кримінальної конкуренції, загроз. Також, економічну безпека підприємства розрізняють як стан стійкості чи рівноваги або ефективного використання його ресурсів. Деякі визначають, що економічна безпека $\epsilon$ залежністю від гармонізації інтересів. Наведено систему показників, що характеризують стан фінансовоекономічної безпеки та відповідають таким вимогам: $є$ простими для розрахунку і для розуміння; суттєвими і значущими; базуються на чинній бухгалтерській та статистичній звітності; оперативними для відповідного реагування на стан фінансової безпеки; характеризують якісний та кількісний стан у статиці і динаміці. Охарактеризовано, що у процесі проведення науковоекономічних досліджень, вирішуються завдання. Розкрито механізм управління економічною безпекою. Визначено, що серед основних методів оцінювання системи фінансово-економічної безпеки визначають: експертних оцінок, регресійного і дисперсійного аналізу, регресійний метод і метод експоненціального згладжування, методи дослідження нечітких систем, кластерний та дискримінантний аналіз. Систематизація методичних підходів до організації наукових досліджень в системі фінансово-економічної безпеки показала, що їх визначають з точки зору ресурсного (інвестиційного) системного, інфраструктурного (кластерного) та процесного підходів. Практичне значення. Наведено дослідження сутності, завдань та методичних підходів організація наукових досліджень в системі фінансово-економічної безпеки, що можуть бути використанні здобувачами та науково-педагогічними працівниками вищої освіти. Перспективи

\footnotetext{
${ }^{1}$ Одеська національна академія харчових технологій; завідувач кафедри економічної теорії та фінансово-економічної безпеки; ідентифікатор ORCID: https://orcid.org/0000-0002-1055-810X; e-mail: rogatina.lida@gmail.com.
}

Економічні горизонти № 3(14)'2020 http://eh.udpu.edu.ua 
подальщих досліджень. Формування організації наукових досліджень в системи фінансовоекономічної безпеки.

Ключові слова: методологія, методичні підходи, методи, фінансово-економічна безпека.

Кількість джерел: 12; кількість таблищь: 1; кількість рисунків: 1; кількість формул: 0.

\section{Introduction.}

In modern economic conditions, there is an urgent need for researched systems of financial and economic security, both at the micro and meso and macro levels. Effective and effective study of the system of financial and economic security necessitates the construction its methodology. Unfortunately, the lack of uniform methodological approaches to the study of the system of financial and economic security forces researchers to formulate new approaches. Therefore, the formation of research methodology in the system of financial and economic security is quite relevant.

\section{Literature review.}

The scientific works of modern economists are devoted to the problems of formation of the theory and methodology of financial and economic security of economic entities, the state security system, security techniques and technologies, in particular: O. Khomiv (2015), I. Irtyshcheva and I. Kramarenko (2011), V. Franchuk (2010), N. Zachosova and A. Kovalenko (2017), P. Prygunov (2013), M. Kopytko (2013), I. Kramarenko and L. Kozachenko (2018), R. Varicheva (2018), I. Zhurba (2018), A. Verhun and K. Strizhko (2018) and others. However, the complexity and versatility of this study requires the formation of the organization of research in the system of financial and economic security.

\section{Methodology.}

The scientific works of scientists in the organization of scientific research of financial and economic security are theoretical and methodological basis of the study. In order to achieve the established goal of the article, the following research methods were used: theoretical generalization - the essence, the system of indicators for assessing financial and economic security; methods of positive and normative analysis - for the development of recommendations for improving the organization of research in the system of financial and economic security.

\section{Research objectives.}

The purpose of the article is to form a methodology of scientific research in the system of financial and economic security.

\section{Results and discussions.}

O. Khomiv believes that in order to the study of economic phenomena and processes, special research is conducted, which is the study of phenomena using certain methods of the essence and processes in order to rationally optimize the purposeful activities of people in material production. Economic research involves the choice of its area, the formation of goals, hypotheses, programming, accumulation and compilation of facts, stable theoretical generalizations, verification of theoretical conclusions, development and practical implementation of measures. It is in their organic unity that these components make up the final cycle of economic research (Khomiv, 2015).

In general, research in the system of financial and economic security is carried out in five areas (Figure 1). Among the areas of research of the system of financial and economic security are: dangerous processes and phenomena occurring in the world economy that can negatively affect the economic security of Ukraine; the level of stability, protection of interests and opportunities of the national economy to counteract the negative impact of the crisis of the world economy; the state of economic security of Ukraine and trends in the development of adverse factors in the national economy and the formation of mechanisms to counter them; the state of eco- 
nomic security of economic entities, external and internal factors of dangers and threats to economic security; features of the organization of the system of economic security of enterprises, the activities of the subjects of its provision and their use of techniques and technologies that make it possible to ensure economic security.

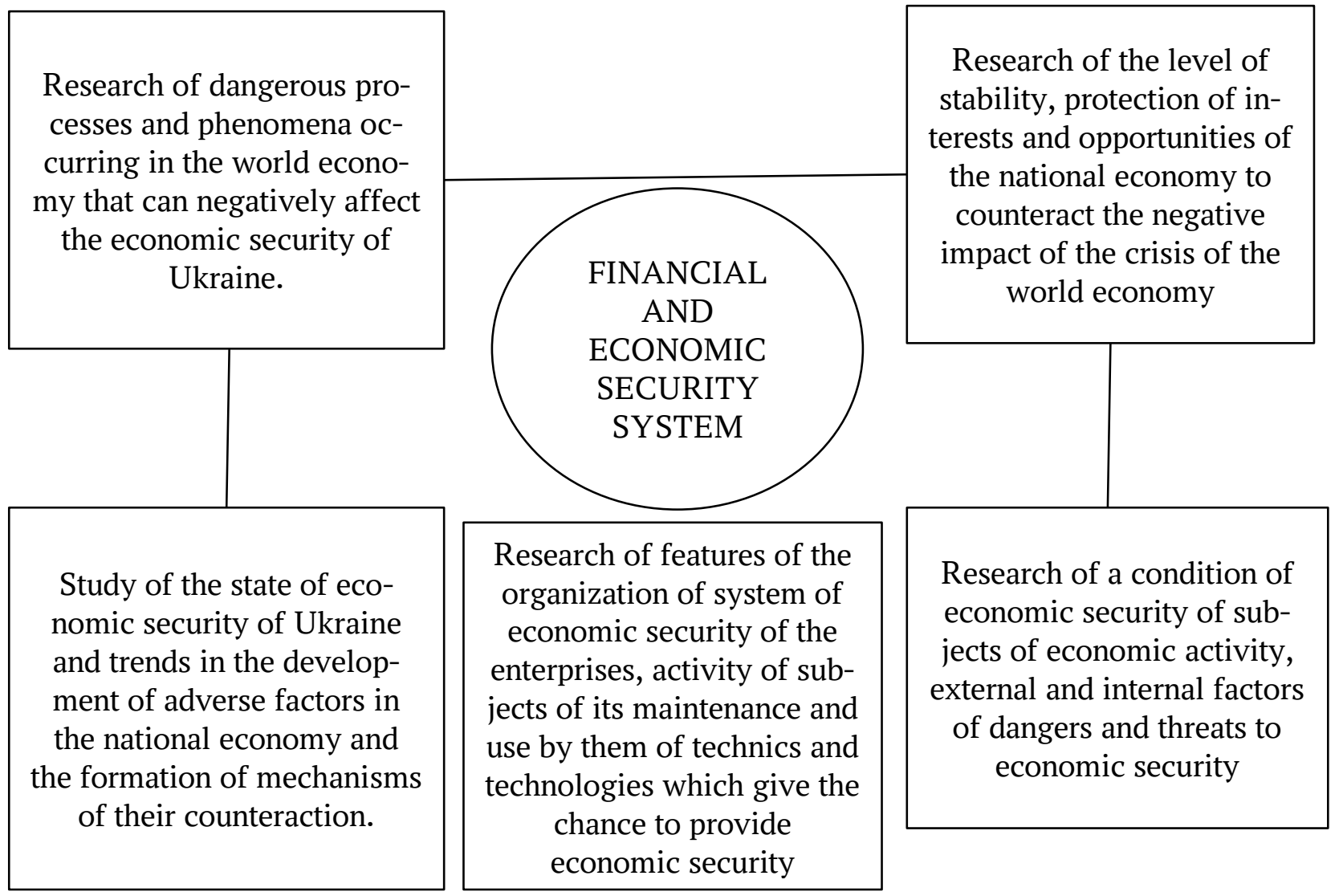

\section{Fig. 1. Areas of methodological research in the system of financial and economic security} Source: (Franchuk, 2010).

An important prerequisite in the process of forming the methodology of the system of financial and economic security is the definition of the principles on the basis of which the philosophy of scientific theory is determined. The main principles of research methodology in the system of financial and economic security are given in Table 1 .

The principle of conformity expressed in the creation of a system of definitions of basic concepts, axioms based on these definitions, theorems of the theory of economic security. These elements of the theory (conceptual apparatus, axioms, lemmas, theorems) form the basis of the laws that determine the state of economic security, as well as mechanisms for its provision. The principle of compliance contributes to the logical progressive development of the knowledge system in the field of economic security.

The principle of additionality allows for the establishment of the place of the theory of economic security in the structure of economic science. Economic security is considered as one of the aspects of the functioning of the economy, with the parameters in its study are the negative manifestations that affect the economic system; target system, which means that the theory of economic security is formed to solve problems of protection of the economy from negative influences by achieving a system of interrelated hierarchically subcontracted and horizontal goals. The principle of hierarchical goals. Which is defined as follows: the security of the upper level of the economic system is a condition for ensuring the economic security of the lower level of the economic system. 
Table 1. Principles of research methodology in the system of financial and economic security

\begin{tabular}{|c|c|}
\hline Principles & Content \\
\hline $\begin{array}{l}\text { The principle of con- } \\
\text { formity }\end{array}$ & $\begin{array}{l}\text { expressed in the creation of a system of definitions of basic concepts, axioms } \\
\text { based on these definitions, theorems of the theory of economic security. } \\
\text { These elements of the theory (conceptual apparatus, axioms, lemmas, theo- } \\
\text { rems) form the basis of the laws that determine the state of economic securi- } \\
\text { ty, as well as mechanisms for its provision. The principle of compliance con- } \\
\text { tributes to the logical progressive development of the knowledge system in } \\
\text { the field of economic security. }\end{array}$ \\
\hline $\begin{array}{l}\text { The principle of addi- } \\
\text { tionality }\end{array}$ & $\begin{array}{l}\text { allows for the establishment of the place of the theory of economic security } \\
\text { in the structure of economic science. Economic security is considered as one } \\
\text { of the aspects of the functioning of the economy, with the parameters in its } \\
\text { study are the negative manifestations that affect the economic system; target } \\
\text { system, which means that the theory of economic security is formed to solve } \\
\text { problems of protection of the economy from negative influences by achiev- } \\
\text { ing a system of interrelated hierarchically subcontracted and horizontal } \\
\text { goals. }\end{array}$ \\
\hline $\begin{array}{l}\text { The principle of hierar- } \\
\text { chical goals }\end{array}$ & $\begin{array}{l}\text { Which is defined as follows: the security of the upper level of the economic } \\
\text { system is a condition for ensuring the economic security of the lower level of } \\
\text { the economic system. }\end{array}$ \\
\hline $\begin{array}{l}\text { The principle of rela- } \\
\text { tive independence of } \\
\text { horizontal goals }\end{array}$ & $\begin{array}{l}\text { is defined as follows: the total impact of economic entities on the state of } \\
\text { economic security of a certain level (segment) decreases as the number of } \\
\text { economic ties between them. }\end{array}$ \\
\hline $\begin{array}{l}\text { Methodological con- } \\
\text { sistency }\end{array}$ & $\begin{array}{l}\text { is expressed in application of a single methodological approach to the study } \\
\text { of economic security, based on determining the state of economic security } \\
\text { through the ability of the economy to withstand the effects of negative influ- } \\
\text { ences. }\end{array}$ \\
\hline Spatial consistency & $\begin{array}{l}\text { suggests that the field of study can be represented as a space that contains } \\
\text { both subspaces, selected on certain grounds, and elements belonging to them, } \\
\text { which helps to identify their characteristic patterns, causes and consequences } \\
\text { that provide a level of economic security. }\end{array}$ \\
\hline
\end{tabular}

Source: Compiled by (Zachosova and Kovalenko, 2017).

The principle of relative independence of horizontal goals is defined as follows: the total impact of economic entities on the state of economic security of a certain level (segment) decreases as the number of economic ties between them.

Methodological consistency is expressed in application of a single methodological approach to the study of economic security, based on determining the state of economic security through the ability of the economy to withstand the effects of negative influences.

Spatial consistency suggests that the field of study can be represented as a space that contains both subspaces, selected on cer- tain grounds, and elements belonging to them, which helps to identify their characteristic patterns, causes and consequences that provide a level of economic security.

The principles of research methodology in the system of financial and economic security include: the principle of conformity (responsible for building a system of definitions of basic concepts, axioms based on these definitions, theorems of the theory of economic security); the principle of additionality (allows the establishment of the place of the theory of economic security in the structure of economic science); the principle of hierarchical goals (ensuring the security of the up- 
per level of the economic system is a condition for ensuring the economic security of the lower level of the economic system); principle of relative independence of horizontal goals, methodological consistency, spatial consistency.

P. Prygunov emphasizes that the problems of economic security of economic entities in the scientific sphere of national security can be considered through the following:

- development of the theory and methodology of ensuring or assessing the state of economic security of the enterprise of a certain industry, the activities of which affect the state of economic security of the country;

- research of threats and dangers that are characteristic of the economic security of the state and affect the activities of domestic enterprises;

- research of the activities of domestic enterprises to counter threats and dangers that affect its activities and are directly or indirectly characteristic of threats to the economic security of the state;

- analysis of economic and financial activities of enterprises, if its activities affect the state of economic security of the country or are specific to a particular industry;

- assessment of the security of enterprises, its leading type of economic activity, subject to consideration of the activities of its security unit or the functioning of the economic security system at the enterprise;

- analysis of the activities of enterprises to ensure their economic security through the activities of the subjects of ensuring its security;

- research of mechanisms to ensure the economic security of economic entities that can be used for enterprises in a particular industry or for most domestic entities;

- research of directions, forms, methods, means, techniques and technologies of ensuring economic security at domestic enterprises, which can be used to ensure the protection of the national economy;

- research of the organizational, legal and economic situation to ensure the func- tioning of the economic security system at domestic enterprises;

- research, establishment and evaluation of criteria and indicators of the state of the economic security system at enterprises depending on the specifics of the leading type of their economic activity;

- research of the interdependence of the state of economic security of the country, the subjects of its provision in relation to the economic security of domestic economic entities;

- research of features of the organization and functioning of security divisions at the domestic enterprises, activity of their experts and their use (Prygunov, 2013).

Depending on the specific author's approach to the formation of the system of economic security, modern scientists distinguish different elements of its structure. M. Kopytko managed to form a generalized list of elements of the economic security system that are offered to enterprises, but can also be used by financial institutions in building their own economic security systems. This list includes: goals, objectives, functions, principles, functional components, mechanism, measures, objects, subjects, economic security policy, economic security strategy, threats, assessment indicators (needs clarification - assessment of what exactly: the state of the system, the effectiveness of its management, etc. - author), means, direct actions of employees to ensure economic security, methods (it should also be specified), bodies, services (we consider it appropriate to include them in the list of subjects of economic security - author), competitive intelligence, counterintelligence, mode of operation (most likely, these are security measures than elements of its system - author) (Kopytko, 2013).

The methodological approaches to the study of financial and economic security include: indicative, resource-functional and program-target. The most common is the indicator approach, the methodology of which is related to the actual values of financial security indicators with threshold values of indicators of its level. 
The indicator approach is characterized by comparing the actual values of financial security indicators with the threshold values of indicators of its level. Thresholds for financial security indicators are thresholds, non-compliance with which leads to the formation of negative trends (threats) in the field of financial security. In this approach, the highest level of financial security of the enterprise is achieved provided that the whole set of indicators is within the threshold values, and the threshold value of each of the indicators is not achieved at the expense of others. Indicators of financial security of the enterprise, on the one hand, should be part of the system of indicators that characterize the conditional structure of financial security of the enterprise as part of the aforementioned functional components (subsystems); on the other hand, - indicators of financial security of the enterprise should be included into the system of indicators characterizing a condition of financial activity of the enterprise, i.e. reflecting a certain condition of this security and to be completely based on indicators of financial activity (Arefieva and Kuzenko, 2009; Horiacheva, 2013).

This approach involves the study of simple functional relationships between individual items of financial statements based on the calculation of a certain sample of indicators (ratios) and their subsequent analysis, which is usually done by:

a) comparison of actual indicators with the established standards (normative method);

b) comparison of the coefficients of the analyzed enterprise with similar indicators of other enterprises of the same industry (comparative analysis);

c) comparison of the coefficients of the analyzed enterprise with similar indicators of leading companies in this field (benchmarking) (Kramarenko and Kozachenko, 2018).

The resource-functional approach provides a comprehensive assessment of the state of use of corporate resources according to certain criteria. Key economic processes are studied, the analysis of distribution and use of resources of the enterprise is carried out, measures for achievement of the highest level of economic security of the enterprise are developed.

The program-target approach is based on the principles of program-target management and development, and the assessment is based on the generalization of indicators that ensure economic security. The application of the approach allows for a reliable assessment of the level of economic security, but is based on the use of mathematical and statistical apparatus, which limits its use in practice due to complexity (Varicheva, 2016).

I. Zhurba noted that the analysis of the methodological basis for the formation of the science of economic security showed the lack of a systematic understanding of this in modern theoretical economics. This is due to the fact that issues of economic security go beyond economic research and are reflected in the system of psychological, sociological and legal sciences. Therefore, the need for interdisciplinary study of economic security of enterprises is justified and provides for the introduction into the system of economic methods and principles of economic research, methods and techniques specific to psychology, sociology, security science, jurisprudence, etc. (Zhurba, 2018).

We must agree with A. Verhun and K. Strizhko, that the analysis of methodological approaches to assessing the level of financial security of the enterprise shows that they have certain shortcomings, namely: assessment of the level of financial security of the enterprise based on analysis of the dynamics of one or more indicators is ineffective, because it does not take into account the systemic nature of financial security when assessing the level of financial security of the enterprise, therefore preference should be given to the use of an integrated security indicator, which is obtained through the use of multidimensional statistical methods; most methods do not take into account the relation- 
ship between financial security and threats. It is important to quantify the relationship between the integrated level of financial security of the enterprise and between threats to financial security; in the analyzed approaches to assessing the level of financial security of the enterprise, scientists focus on current and retrospective assessments of the level of security, without stopping their attention on forecast estimates for the future (Verhun and Strizhko, 2016).

In general, the formation of research methodology in the system of financial and economic security should be based on areas, principles and methodological approaches.

\section{Conclusions.}

It is proved that the basic strategic Research in the system of financial and economic security has been proven to be carried out in five areas. Among the areas of research of the system of financial and economic security are: dangerous processes and phenomena occurring in the world economy that can negatively affect the economic security of Ukraine; the level of stability, protection of interests and opportunities of the national economy to counteract the negative impact of the crisis of the world economy; the state of economic security of Ukraine and trends in the development of adverse factors in the national economy and the formation of mechanisms to counter them; the state of economic security of economic entities, external and internal factors of dangers and threats to economic security; features of the organization of the system of economic security of enterprises, the activities of the subjects of its provi- sion and their use of techniques and technologies that make it possible to ensure economic security.

The basic principles of research methodology in the system of financial and economic security have been provided. The principles of research methodology in the system of financial and economic security include: the principle of conformity (responsible for building a system of definitions of basic concepts, axioms based on these definitions, theorems of the theory of economic security); the principle of additionality (allows the establishment of the place of the theory of economic security in the structure of economic science); the principle of hierarchical goals (ensuring the security of the upper level of the economic system is a condition for ensuring the economic security of the lower level of the economic system); principle of relative independence of horizontal goals, methodological consistency, spatial consistency.

The methodological approaches to the study of financial and economic security have been proven include: indicative, resourcefunctional and program-target.

The most common is the indicator approach, the methodology of which is related to the actual values of financial security indicators with threshold values of indicators of its level. Evaluation using a program-targeted approach provides an analysis of the state of use of corporate resources according to certain criteria. The resource-functional approach provides a comprehensive assessment of the state of use of corporate resources according to certain criteria.

\section{References}

Arefieva, O. V. and Kuzenko, T. B. (2009), "Economic basis for formation of financial constituent of economic security”, Current economic problems, no. 1. pp. 98-103.

Franchuk, V. (2010), Osoblyvosti orhanizatsii systemy ekonomichnoi bezpeky aktsionernykh tovarystv $v$ umovakh transformatsii ekonomiky [Features of the organization of the system of economic security of domestic joint-stock companies in the conditions of transformational economy], Lvivskyi derzhavnyi universytet vnutrishnikh sprav, Lviv, Ukraine, 440 p.

Horiacheva, K. S. (2003), "Information and analytical support of financial security of the enterprise", Actual Problems of Economics, no. 1, pp. 98-103.

Irtyshcheva, I. O. and Kramarenko, I. S. (2011), "Methodical approaches to assessing the creditworthiness of agri-food enterprises”, Agrosvit, no. 19, pp. 2-4. 
Khomiv, O. (2015), "Features of lead through scientifically economic researches", Efektyvna ekonomika, [Online], no. 5, available at: http://www.economy.nayka.com.ua/?op=1\&z=4048 (Accessed 20 July 2020)

Kopytko, M. (2013), "Analysis of theoretical approaches to defining the concept and components of the system of economic security of enterprises", Scientific Bulletin of Kherson State University. Series: Economic Sciences, no. 3, pp. 59-64.

Kramarenko, I. and Kozachenko, L. (2018), "Methods of assessing the creditworthiness of the borrower: A practical aspect”, Economy of Ukraine, no. 5, pp. 49-61.

Prygunov, P. Ya. (2013), "Formation of theoretical and methodological approaches to the study of economic security of economic entities in the area of national security", Naukovi pratsi MAUP, vol. 4(39), pp. 160168

Varicheva, R. (2016), "Methodical approaches to assessing the quality of economic security of the enterprise: accounting support", Khmelnytskyi National University Bulletin, no. 3. no 1, pp. 88-93.

Verhun, A. M. and Strizhko, K. V. (2015), "Modern approaches to assess the level of the company financial security", Efektyvna ekonomika, [Online], no. 6, available at: http://www.economy.nayka.com.ua/?op=1\&z=4142 (Accessed 20 July 2020)

Zachosova, N. and Kovalenko, A. (2017), "Methodology of scientific research of problems of ensuring economic security of the state", Ekonomika ta derzhava, vol. 11, pp. 56-59.

Zhurba, I. O. (2018), "The essence of economic security of enterprises in the region", Proceedings of Scientific Works of Cherkasy State Technological University Series Economic Sciences, vol. 48, pp. 124-130, doi: https://doi.org/10.24025/2306-4420.0.48.2018.127362

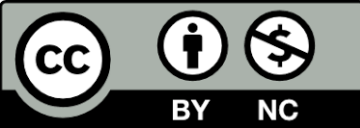

Цей твір ліцензовано на умовах Ліцензії Creative Commons «/з Зазначенням Авторства - Некомерційна 4.0 Міжнародна» (CC BY-NC 4.0). This is an open access journal and all published articles are licensed under a Creative Commons "Attribution-NonCommercial 4.0 International" (CC BY-NC 4.0). 